\title{
Evaluation of the Physicochemical and Heavy Metal Properties of Igwi-Stream in Abia State University, Uturu, Abia State, Nigeria.
}

\author{
Ogwo, P. A ${ }^{1}$, Okoronkwo, C. U., ${ }^{2}$ Okereke, V. E². And Udensi, E. A ${ }^{2}$ \\ ${ }^{I}$ Department of Environmental Management \&Toxicology, Michael Okpara University of Agriculture, Umudike, \\ Nigeria. \\ ${ }^{2}$ Department of Food Science and Technology, Abia State University, Uturu
}

\begin{abstract}
Igwi stream is the major source of water supply to more than fifteen thousand members of Abia State University community. The Physicochemical and heavy metal content of Igwi-stream were studied on 2000ml of the water sample. The objective is to establish preliminary data on the stream with a view determine if the quality of the water meets standard for drinking and domestic uses. The results of the physicochemical analysis revealed that $\mathrm{pH}$ of the stream water sample was 5.0 which indicated some level of acidity in the stream which deviated slightly from the recommended standard of (6.5) WHO (2010). The pH of 5.8 was observed in the downstream which was very close to the recommended level of 6.5 by NAFDAC, USEPA and WHO.

Total hardness $(8 \mathrm{mg} / \mathrm{L})$, total alkalinity $(0.4 \mathrm{mg} / \mathrm{L})$, sulphate $(12.85 \mathrm{mg} / \mathrm{L})$, chloride $(82 \mathrm{mg} / \mathrm{L})$, total solid $(0.006 \mathrm{mg} / \mathrm{L})$ and total dissolved solids $(0.003 \mathrm{mg} / \mathrm{L})$. The parameters obtained were below the recommended standard of World Health Organization (WHO). The results obtained from the sample show the heavy metal contents as follows; lead $(0.002 \mathrm{mg} / \mathrm{L})$, zinc $(0.011 \mathrm{mg} / \mathrm{L})$, copper $(0.013 \mathrm{mg} / \mathrm{L})$, iron $(0.011 \mathrm{mg} / \mathrm{L})$, cadmium $(0.00 \mathrm{mg} / \mathrm{L})$, and chromium $(0.011 \mathrm{mg} / \mathrm{L})$, these heavy metals content were found to be within the recommended level of acceptance for WHO (2004) except zinc. Cadmium was not found in the downstream and upstream samples.
\end{abstract}

Keywords: Abia State University, surface water, Igwi-Stream, Nigeria

\section{Introduction}

Water is a common resource quite abundant in nature, but unfortunately not readily available to man in the form desired. Water is fundamentally important to all plants, animals and man (Ajewole, 2005).

Water is essential for life. It is significant due to its unique chemical and physical properties, water is made up of two atoms of hydrogen and one atom of oxygen $\left(\mathrm{H}_{2} \mathrm{O}\right)$, and because of the unique nature of binding, water is a solvent for many minerals and can be referred to as a universal solvent for many minerals (Mbagwu, 2003).

It can exist in three states as liquid, gas (above $100^{\circ} \mathrm{C}$ ) and as solid (at freezing temperature of below $4^{0} \mathrm{C}$ ).

Water is the matrix of life as all biological reactions occur in water and are the most versatile chemical formed within any metabolizing cells (Prescott et al.,2002) Since the beginning of recorded history, water has been recognized as a potential carrier of diseases. Therefore, water meant for human consumption should be devoid of objectionable odour, turbidity, enteric pathogenic bacteria and must not fluctuate in its quality (Dawson and Spartory, 2000).

The important use of water cannot be over-emphasized; water constitutes up to $70.2-80.1 \%$ by weight of a eukaryotic cell and profoundly influences all molecular interaction in biological systems (Prescott et al., 2002). It is estimated by the World Health Organization (WHO) that up to $80 \%$ of illness worldwide are related to inadequate supply of potable water (Ajewole, 2005).

The source of water can be grouped into three namely; rain water, surface water (river, stream, lake, lagoon, sea etc) and underground water (well water and borehole water) (Oyobode, 2005). Umeham, 2014 reported that the sanitary quality of water is the relative extent of the absence of suspended matter, colour, taste, unwanted dissolved chemicals, bacteria indicative of faecal pollution and other aesthetically offensive objects. In safeguarding public water supplies, the first step is the selection of the best available source of water. The most protected source of water will be the easiest and cheapest to transform into safe drinking water (Okafor, 1985). Some ways by which water can be polluted was elaborated by Umeham, 2014 as follows; agricultural waste, microorganisms, volcanic eruption, industrial activities, man- made sources. These wastes can change the level of hydrogen iron concentration, $(\mathrm{pH})$, which can result to harmful effects on plants, aquatic animals and human use. Aeration, distillation, chlorination, ozonization, boiling and U.V radiation have been described to be used for water treatment (Ugunwa, 2005).

The purpose of this work is to evaluate the physicochemical and heavy metal content of Igwi stream located in Abia state University, Uturu, Abia State Nigeria. 


\section{Materials And Methods}

The stream water sample used for this study is located at 10 kilometers away from Abia State University, Uturu in Isuikwuato Local Government Area, Abia State Nigeria. The sample was aseptically collected in a sterile $2000 \mathrm{ml}$ glass bottles, and kept between the temperature of $4-10^{\circ} \mathrm{C}$ and transported to the laboratory in less than 6 hours after collection. The sample was analyzed within 24hours of collection (Okoronkwo, et al., 2013).

\subsection{Physicochemical Analysis}

The determination of the $\mathrm{pH}$ value was carried out by measurement of the potential different between electrode immersed in standard test solution according to EPA, (2009). Total hardness (mg/L) was determined by the EDTA titrimetric method of Ebena et al., (1999).

Alkalinity of Igwi-stream was determined by the spectrometric method adopted by Ibeh and Bakare, (2002). Absorbance was read in a $420 \mathrm{~nm}$ wavelength. Phosphate was also determined by the method of James (1995) using the titrimetric method. Chloride determination was also done by the titrimetric method of Kumar et al., 1999. Total solids and total dissolved solids were determined by the gravimetric method according to Kumar, 1999. Whereas total suspended solids was determined by difference between total solid and total dissolved solids used by Ebena et al., 1999. Electrical conductivity was determined by dividing the factors of total dissolved solids by the factor 0.725 (standard) according to EPA,( 2009) .

\subsection{Heavy Metal Determination}

The heavy metals of interest were zinc, lead, copper, cadmium, iron and chromium. They were all analyzed using the Atomic Absorption Spectrophotometer (AAS) according to Umeham and Okereke (2005), Odom, et al., (2003).

\section{Results And Discussion}

TABLE 1.0: Physicochemical Analysis of Igwi-Stream (upper stream)

\begin{tabular}{|l|l|l|l|l|}
\hline Parameters & Ups & WHO & USA & NIG \\
\hline $\mathrm{pH}$ & $5 \mathrm{mg} / \mathrm{L}$ & - & $65-8.6$ & $6.5-8.5$ \\
\hline Total Hardness & $8 \mathrm{mg} / \mathrm{L}$ & - & 100 & - \\
\hline Total alkalinity & $0.4 \mathrm{mg} / \mathrm{L}$ & - & 250 & - \\
\hline Sulphate & $12.85 \mathrm{mg} / \mathrm{L}$ & 500 & 100 & 100 \\
\hline Phosphate & $48.31 \mathrm{mg} / \mathrm{L}$ & $45-50$ & - & $46-50.2$ \\
\hline Chloride & $82 \mathrm{mg} / \mathrm{L}$ & 250 & 200 & 250 \\
\hline Total solid & $0.006 \mathrm{mg} / \mathrm{L}$ & - & 500 & - \\
\hline Total dissolved solid & $0.003 \mathrm{mg} / \mathrm{L}$ & - & - & 500 \\
\hline Electrical conductivity & $0.004 \mu / \mathrm{ml}$ & - & 1000 & 1000 \\
\hline Total suspended solid & $0.003 \mathrm{mg} / \mathrm{L}$ & - & - & - \\
\hline Total & 156.576 & & & \\
\hline Mean & 15.657 & & & \\
\hline
\end{tabular}

Table 1.0 showed the physicochemical examination of water sample of Igwi-stream taken from the upper stream. The $\mathrm{pH}$ was below the World Health Organization standard and United Nation Standard. The $\mathrm{pH}$ show slight acid in the water making it unsafe for drinking purpose. This could be attributed to the release of $\mathrm{CO}_{2}$ into the atmosphere from exhaust pipe of the generator situated in the pump house close to the stream in Abia State University Uturu.

The alkalinity of the sample is $0.4 \mathrm{mg} / \mathrm{L}$ which is quite low compared to the available standards. Total hardness recorded $8 \mathrm{mg} / \mathrm{L}$ which is also lower than the standard. This proves that calcium and magnesium are low in the water sample. It also indicates that the water sample can easily form later with soap (Okoronkwo et al., (2013).

Sulphate recorded $12.85 \mathrm{mg} / \mathrm{L}$ which indicated lower results when compared to Nigeria's (NAFDAC) and World Health Organizations standard. The result explained that the minerals of the soil where the stream is located are not fully oxidized by sulphur containing minerals and organic compounds.

Phosphates level maintained an agreeable level of the World Health organization i.e. $48.31 \mathrm{mg} / \mathrm{L}$. In this case, the stream water may be used for domestic activities only. 
TABLE 2: Physicochemical Analysis of Igwi Stream (down stream)

\begin{tabular}{|l|l|l|l|l|}
\hline Parameters & Water sample & WHO & USA & NIG \\
\hline $\mathrm{pH}$ & $5.8 \mathrm{mg} / \mathrm{L}$ & - & $6.5-8.6$ & $6.5-8.5$ \\
\hline Total hardness & $0.10 \mathrm{mg} / \mathrm{L}$ & $95-105$ & 100 & - \\
\hline Total alkalinity & $0.8 \mathrm{mg} / \mathrm{L}$ & - & 250 & - \\
\hline Sulphate & $15.85 \mathrm{mg} / \mathrm{L}$ & 500 & 100 & - \\
\hline Phosphate & $58.31 \mathrm{mg} / \mathrm{L}$ & - & 200 & 100 \\
\hline Chloride & $92 \mathrm{mg} / \mathrm{L}$ & 250 & 500 & - \\
\hline Total solid & $0.009 \mathrm{mg} / \mathrm{L}$ & - & - & 250 \\
\hline Total dissolved solid & $0.006 \mathrm{mg} / \mathrm{L}$ & - & 1000 & - \\
\hline Electrical conductivity & $0.008 \mu / \mathrm{ml}$ & - & - & 500 \\
\hline Total suspended solid & $0.008 \mathrm{mg} / \mathrm{L}$ & - & & 1000 \\
\hline
\end{tabular}

Table 2 explains the physicochemical results of Igwi stream in the downstream station. The $\mathrm{pH}$ of the downstream location recorded $5.8 \mathrm{mg} / \mathrm{L}$ which was in tandem with the World Health Organization's. standard of 6.5 to 8.6. The differences in the results of the two location could be attributed to the natural purification of water as opined by Ugbogu, (2010) and reported by Okoronkwo et al.,(2013) ${ }^{\mathrm{a}}$.

The alkalinity of the water of Igwi stream in the downstream recorded $0.8 \mathrm{mg} / \mathrm{L}$ against the recommendation of United State of America $(250 \mathrm{mg} / \mathrm{L})$, the cause may be as a result of three factors e.g. hydroxide (strong base), carbonates and hydrogen carbonate (Ugbogu, 2010).

The result of total hardness recorded $10 \mathrm{mg} / \mathrm{L}$ which is far below the recommended standard of NAFDAC (Nigeria). The result shows that calcium and magnesium are merely low in the Igwi-downstream location. The sample can also form lather with soap as observed in the upper stream. The result do not agree with the finding of Okoye,(1991) in natural purification of water. This could be as a result of the slow flow of the stream along the down course. Sulphates and phosphate are also low in the downstream location of Igwi-water sample. This explains that minerals of the soil from where the stream is located are not fully oxidized by sulphur and phosphorus containing minerals and organic compounds.

TABLE 3 Heavy Metal Content of the Upper Stream Water Sample in Igwi River

\begin{tabular}{|c|c|c|c|c|}
\hline Heavy metal (Minerals) & Level of the mineral in the sample & USA Standard & $\begin{array}{l}\text { WHO } \\
\text { Standard }\end{array}$ & $\begin{array}{l}\text { NAFDAC } \\
\text { (Nigeria) }\end{array}$ \\
\hline Lead (mg/L) & 0.002 & 0.01 & 2.0 & 1.0 \\
\hline Cadmium (mg/L) & 0.000 & - & 0.003 & 0.003 \\
\hline Iron $(\mathrm{mg} / \mathrm{L})$ & 0.011 & 0.3 & - & 0.3 \\
\hline Chromium (mg/L) & 0.011 & - & 0.05 & 0.05 \\
\hline Mean total & 0.008 & & & \\
\hline
\end{tabular}

Heavy metals are common constituents of natural water bodies. Although some are essential for living organisms, they may become toxic when present in high concentrations. From the table above, all the minerals are within the level of acceptance by the World Health Organization, and NAFDAC (Nigeria), except zinc which is below the standard and cadmium was not detected in the upper stream. The difference from the two locations could be because of heavy metal sedimentation as reported by Ibe and Bakare, (2002).

TABLE 4: Heavy Metal Content of Igwi Stream in the Downstream Location

\begin{tabular}{|l|l|l|l|l|}
\hline Minerals & Level of the mineral in the sample & USA & WHO & NIG \\
\hline Zinc $(\mathrm{mg} / \mathrm{L})$ & 0.021 & 5.0 & 3.0 & 3.0 \\
\hline Lead $(\mathrm{mg} / \mathrm{L})$ & 0.031 & 0.01 & 0.01 & 0.01 \\
\hline Copper $(\mathrm{mg} / \mathrm{L})$ & 0.015 & 1.20 & 2.0 & 1.0 \\
\hline Cadmium (mg/L) & Nil & - & 0.003 & 0.003 \\
\hline Iron (mg/L) & 0.012 & 0.30 & - & 0.30 \\
\hline Chromium (mg/L) & 0.013 & - & 0.05 & 0.05 \\
\hline Total & 0.092 & & & \\
\hline Mean total & 0.015 & & & \\
\hline
\end{tabular}

Table 4 specifies the level of heavy metals analyzed in the downstream location of igwi-stream. All the heavy metals of interest were present except cadmium. The level of zinc $(0.021 \mathrm{mg} / \mathrm{L})$ was low compared to the standard of World Health Organization $(3.0 \mathrm{mg} / \mathrm{L})$, Standard Organization of Nigeria $(3.0 \mathrm{mg} / \mathrm{L})$ and United State Environmental Protection Agency (USEPA). All other heavy metals analyzed agreed with the level of the USEPA, WHO and SON standard. 


\section{Conclusion And Recommendation}

From the physicochemical analysis conducted in the downstream and upstream location of Igwi stream, the $\mathrm{pH}$ of $5.0 \mathrm{mg} / \mathrm{L}$ and $5.8 \mathrm{mg} / \mathrm{L}$ respectively show slight acidity on the stream. The heavy metals analyzed are in the level of acceptance for USEPA, SON and WHO except zinc that deviated from the standard. The total dissolved solids (TDS) values were in consonance with FEPA water quality guidelines for brewing criteria according to Charlotte de Fraiture (2012). Cadmium was not detected in the sample (downstream and upstream). The quality of the water sample is poor for direct consumption without treatment, due to the slight detected acidity in the sample, the sample tends to have an imbalance $\mathrm{pH}$ which affects the cellular activity in the body system leading to the progression of most degenerative disease (Kirk, 2002).

Therefore, the need for water treatment becomes paramount since the stream becomes contaminated by substances present in it or introduced by man as a consequence of various activities undertaken on earth for survival (Umeham, 2014).

\section{Recommendation}

Now that the physicochemical and heavy metal content of igwi-stream have been documented, more research should be done on the microbiological standard of Igwi-stream in Abia State University, Uturu. Hence that the water serves as a point source to the University community, we, therefore, recommend that better treatment should be conducted before using the water for drinking purpose (Bora, 2013). Most of the water bodies were soft and therefore the use of this water for laundry and other forms of cleaning would be a profitable venture since they will very easily form lather with soap (Umeham, 2014). In the sustenance of aquatic system, Umeham and Okereke (2005), suggested that liming of the water bodies to buffer the effect of the recorded plankton production and consequent fish yield of the water becomes necessary, therefore, we so recommend liming.

\section{References}

[1]. Ajewole, G. (2005). Water. An overview. Food forum magazine, Nigerian institute of food science and technology, (NIFST). P.15.

[2]. Bora, C. (2013). Industrial water pollution. "Buzzle buzzle. n.d web.http://:www.buzzle.com/articles/industrialwaterpollution.html, assessed April 2014.

[3]. Charlottle de Fraiture, (2012). Water and food security in an insecure world: Inaugural address at UNESCO. IHE Institute for Water Education. Delff, the Netherlands 40pp.

[4]. Dawson, D.Y., and Spartory, D.P (2000). Microbiological safety of water: British Medical Bulletin. 56(1) pp 74-78.

[5]. Ebena, R.U.B., Efiok, C.A., and Alike, Y.E. (1999). Physicochemical and bacteriological assessment of selected water sources in Calabar. Int. J. Trop. Env. 1:15-27.

[6]. EPA, (2011). Abattoirs. www.environment.sa.gov.au/epa/pdfas/epwq/policy.polt. assessed, June 2014.

[7]. Ibeh, K.M. and Bakare, A.S (2002). The environmental impact assessment of surface and groundwater of Lagos are south west Nigeria. World J. Biotechnol. 441-414.

[8]. James, C.S (1995). Analytical chemistry of foods. First edition. Chapman and Hall.

[9]. Kirk, L.A (2002). Studies on the hormonal activity of wastewater during its treatment. PhD thesis submitted to the Department of Biological Science. Brunnel University Uxbridge, Middlesex, UB83PH. 230pp.

[10]. Mbagwu, H.C. (2003). Water chemistry outlines (with treatment) A.I.S.T. pp. 1-11.

[11]. Odakuma, L.O and Abbah, A.E (2003). Heavy metal biosorption by three bacteria isolated from a tropical river. Glob. J. Envi. Sci. 2(2):98-100.

[12]. Odon, T.C., Udensi, E.A., and Iwe, M.O (2013). Nutritional evaluation of unripe carica papaya. Unripe musa paradisiaca and mucuna cochichrinesis, weaning food formulation. European J. Biol. Med. Sci. (1)2: 6-15

[13]. Ogunwa, O.B. (2005). "Don't drink that water" purify it first. Food forum magazine. Nigeria institute of food science and technology. P 16.

[14]. Okafor, N. (1985). Water resources, wetlands and fresh water ecology. Pp. 30-49.

[15]. Okeye, B.C.O (1991). Nutrients and selected chemical analysis in the Lagos lagoon, surface waters. Inter J. Env. Studies. V. 38:131-134.

[16]. Okoronkwo, C.U., Ogwo, P.A., Nwachukwu, N.O., and Etusim, P.O (2013)a . Impact of abattoir effluents on physicochemical properties of Aku stream, Abia State, Nigeria. Journal of physical and environmental safety, Vol. 3, No. 1.80-89.

[17]. Okoronkwo, C.U., Ogwo, P.A., Nwachukwu, O.N and Etusim, P.E. (2013) . Impact of grazing on bacteriological properties of Aku stream, Abia State, Nigeria. J. Phy. Env. Safety. Vol. 3, No 1. 112-120.

[18]. Oyebode, J. (2005). Water pollution and sanitation. Food forum magazine: Nigeria Institute of Food Science and Technology (NIFST) P. 15.

[19]. Prescott, L.M (2002). Microbiology ( $5^{\text {th }}$ edition). McGraw-Hill educational publishing, pp. 651-698.

[20]. Ugbogu, O.C (2010). Environmental Microbiology first edition. EBW Publishing Co. P. 94-110.

[21]. Umeham, S.N (2014). Water is life, water is death, ... an ultimate resources, $17^{\text {th }}$ inaugural lecture, ABSU, Uturu, Abia State Nigeria $105 \mathrm{pp}$.

[22]. Umeham, S.N and Okereke, H.C. (2005). Some aspects of the limnology of Iyi oghighe, a stream impacted with refined petroleum products in Isuikwuato LGA of Abia State, Nigeria. Journal of Health and Visual Sciences, Vol. 7, No, 2.

[23]. WHO (2005). World Health Organization: Report on Public water supply. Pp. 4-11.

[24]. WHO (2007). Safe water and global health publication, World Health Organization. P. 33.

[25]. WHO (2010). World Health Organization, guide for drinking water quality, revised publication ( $4^{\text {th }}$ edition). Pp $103-106$. 